\title{
ANALISYS OF THE AXIOLOGICAL-SOCIAL, INSTYTUTIONAL AND LEGAL SPHERE OF THE FAMILY POLICY IN SELECTED EU COUNTRIES
}

\author{
Arkadiusz Durasiewicz \\ Janusz Korczak Pedagogical University in Warsaw, POLAND
}

\begin{abstract}
The article presents the European models of family policy divided into 5 models the Scandinavian model, southern European model, conservative, liberal and post-socialist. In each of these the characteristics of policy for families are presented and divided into: axiological conditions, demographic, institutional family support, legal and family policy instruments. An overview of the various issues in the field of family policy is so important that the implementation of the effective family policy contributes to increased fertility, and thus of human capital, social and creative of the country. The article concludes with a summary and recommendations by individual models.
\end{abstract}

Keywords: family, institutional and legal analysis, family policy models, instruments of family policy, socio-axiological.

\section{Introduction}

An extremely important issue for each country seems to be the implementation of effective family policy. Social interest in children stems from the fact that they represent the potential future labor resources. It is an essential factor of economic development of each country. The role of the family in the processes of development has a dimension of quantitative and qualitative results, and the exercise of its social functions: procreation - crucial for the development of quantitative and population structure; educational and socialization with significance for the creation and development of human capital. This justifies the need for a population policy that will ensure at least a simple reproduction of the population. It is important to show which state instruments (legal, economic) implement family policy. Evaluation of the effectiveness of economic instruments of family policy (including cash family benefits) is a key element of her. Effective family policy must also provide a free choice of family model, and above all a free choice of each of both parents, if he wants to continue working after starting a family and how to care for the child. That free choice embodied in the right of women to self-determination if they want to combine having children with the further development of their careers. Such a system of family support on the one hand creates an opportunity for economic and demographic dynamics of the country, on the other hand, brings evidence that 
the activity of women does not have to play stopping role for reproductive decisions (Durasiewicz, 2012, 6).

In all European countries, except Iceland, birth rates will not even enable maintaining of the current population. Without a reversal of this trend, by 2050 the population of some European countries may drop by up to $30 \%$. For the economy could mean a permanent recession. For society it can create a conflict between the younger and older generation. For Europe - marginalization in the international arena, with all the economic, political and cultural consequences. Therefore, now more clearly sets the goal of reversing the population decline. The aim of the new family policy should first be enabling people to have as many children as they want. Ideally, each woman gave birth to an average of at least 2.1 children, which would provide a simple reproduction of generations. It is not known whether it will bring the expected results. Birth rates would have to rise substantially because today in order to 50 years for Europe to maintain the size of its population. Today, more and more worrying is the increase in the number of European countries, which have a negative natural growth, which means that there is no replacement of generations and reduces the number of citizens of the country. The most important contemporary challenges of family policy are as follows:

- demographic challenges - occurring in the countries of the European Union, although on a different scale and intensity (decrease tendency to marry, the development of new forms of family life, the decline in fertility rates constitutes one of the causes of aging societies);

- socio-economic - the desire to strengthen the competitiveness of the EU economy and, therefore, the need for human capital development; the labor market situation which is characterized by unemployment, unstable employment, the development of new forms of employment, the intensity of the processes activity of women, civil society development, the pursuit of social cohesion through the elimination of poverty and social exclusion;

- axiological challenges - on the one hand, the development of values and attitudes characteristic of the post-industrial society, on the other to maintain a high-ranking of family in the hierarchy of values.

\section{European models of family policy - general characteristics}

Traditionally, family policy was oriented primarily on a family with children. Also today offspring is regarded as ,the most important asset of the future" and is the criterion for determining family type - the subject of interest in politics. Today, there is more and more talk of the need for widening the circle of the recipients of the elderly. They speak for the aging population and its 
implications for family functioning. you can still today expected to encounter, although less frequently, with doubts about the need for this type of policy but we can not forget the role of the family as an institution within which we come into the world and grow. Changes inside her, her, relationships with other institutions have an impact on the entire society. it is not surprising that we are interested in the fate of families in general and manifestation of this concern is the creation of family policy (Durasiewicz 2013, 134).

National family policy is influenced by demographics, economic, social and cultural characteristic of the country. It fits, as social policy, within particular model welfarestate. Therefore, the tendency applies to all EU countries, however, due to the diversity of conditions and cultural processes, countries choose blended policy mix in this situation.

This section presents solutions of family policies in different countries representing different models. The Nordic model (Finland, Sweden, Denmark), the Southern (Greece, Italy, Spain, Portugal), Central-European (Germany, France, Belgium, the Netherlands, Austria, Luxembourg), liberal (UK, Ireland) and Post-Socialist(Poland, Bulgaria Slovakia). Described countries and models developed solutions which can be used in Polish family policy.

\section{The Scandinavian model (social democratic)- Finland, Sweden, Danmark}

\section{Axiological conditions}

In the Nordic countries the family model is based on values such as: (Balcerzak-Paradowska 2004, 174; Anioł 2013, 113; Durasiewicz 2013, 141):

- Equivalence of pro-family and pro-professional orientation in social awareness. Family scores highly in the hierarchy of values of the young generation. Equally high position takes work and career, but they have not the competitive" value.

- The gradual evolution of the relationship between the spouses in the direction of the partnership. The family is most frequently perceived as an institution, which is based on a contract between two economically independent partners. However, partnership, in providing family the economic basis of existence does not translate into equal sharing of responsibilities within the family. Most of the work related to household and childcare are carried out by women. There has been a gradual transformation of behavior, which consists of the increasing participation of men in the care of children.

- Providing children with a high level of development, mainly through the participation of fathers in the processes of education, socialization 
and education.

- There has been far-reaching changes in the field of sexual morality and the formation of informal relationships (cohabitation).

- Another factor that strongly influences the formation and functioning of families and the development of family policy is the participation of women, including women with children. The high activity of women is associated with the belief that the work brings not only financial benefits, but it also has the autotelic value, a source of satisfaction and fulfillment.

- Currently, the dominant purpose in Scandinavia is the actualization of the working family model with a double breadwinner and protector. (work-family model of dual earners and dual careers)

\section{Demographic conditions}

The values for family life are manifested in the processes of formation and functioning of the family; these processes can be characterized as follows (Eurostat Yearbook 2012 \& Testa 2012):

- Decreasing the number of people associated with the decrease in the birth rate.

- Extended life expectancy. 80 years for women and for males 74.3. Sweden is a country where there has been a high rate of men's life expectancy. (78.5).

In terms of fertility, the situation is as follows:

- The number of live births has remained at a similar level since 2005, but now has a growing trend (2013-2014) The fertility rate shows a downward trend and does not guarantee the replacement rate (the lowest in Denmark 1.72, the highest in Sweden, 1.90) .

- The average age of childbearing is at a level of 30.4 .

- In the case of marriages and family formation attitudes in the Nordic model, the situation is as follows:

- For several years, there is a decrease in the number of marriages.

- There are an increasing number of partnerships (in Sweden and Finland, around 5 per 1000 inhabitants). The consequence of this is the growth of extramarital births in the total number of live births.

- There are an increasing number of divorces (an average of a thousand marriages comes to approx. 400 divorces), which is not a high number compared to other EU countries.

- In the structure of families they are dominated by families with fewer children, especially with one child. 
- $\quad$ The consequence of divorce and births outside marriage is to expand the scale of single parenthood. In recent years, noticeable it is the bringing up of children by their fathers - usually caused by the death of a spouse.

- More than $1 / 3$ of the population lives alone. Among the younger generations prevail single men, due to the fact that women often live with their children, however, men get married later than women. Moreover, among the younger generations are more men. The trend is reversed in the case of older people - this group is dominated by women living alone, who generally live longer than men.

\section{Institutional family support}

A characteristic feature of the Scandinavian family policy model is the dominant role of the state as the main subject. Instruments such as public services and welfare cash benefits Scandinavians consider as a manifestation of the positive state interference in family life.

Much of the family policy is conducted at the local level by local governments. They have become the subject of implementing family policy, although, in many cases their action is supported by the central budget (Balcerzak-Paradowska 2004, pp. 175-176; Balcerzak-Paradowska, Kołaczek, Głogosz 2009, pp. 113120).

\section{Legal circumstances}

In the social democratic model the state has a decisive role. Universal, generous social benefits are combined with activation policies and aimed at transferring as many people, both men and women to the sphere of employment. Family policies of these countries are based on the idea of individualization of civil rights, including the individual rights of the child, regardless to their family of origin, the rights of the elderly and disabled, consider providing equal opportunities to women and men by the dominant role of the state and universalism. The national legal acts apply related to the benefits for families divided for various forms of support.

\section{Family policy instruments}

Family policy in Nordic countries (Finland, Sweden, Denmark) is based on the idea of individualization of civil rights, including the individual rights of the child, regardless of their origin, the rights of the elderly and disabled where 
equal opportunities for women and men are taking into account. The dominant instrument of this policy are social services, rather than cash benefits.

It must be emphasized that the Scandinavian model is worth attention because of the wide range of social benefits, designed to meet the different family's and children needs and also to facilitate the reconciliation of work and family responsibilities. The characteristics of this system are (Durasiewicz 2012, pp.73-74):

- As part of supporting early childhood - parental leave for mothers and fathers of at least 158 days,

- As part of creating conditions for the development of the young generation - family allowances for all families, universal system,

- Development of social services for children and youth - 85\% cofinancing from the state budget for nurseries and kindergartens, allowance of a child care at home, a special allowance paid in the case of giving the child into the care of a private institution,

- Supporting families with many children through increased family benefits,

- Helping to a single-parent families - dual system of survivors' pensions, social insurance pension.

\section{South European model (Mediterranean) - Greece, Italy, Spain, Portugal}

\section{Axiological conditions}

South European model of family policy is based on the following values (Balcerzak-Paradowska 2004, 179; Chełstowska \& Zarzyńska 2014, 13-14; Durasiewicz 2013, 143):

- The family occupies a high rank among the hierarchy of values, which are the source of religious codes.

- Children are very much appreciated.

- Interfamily relations are based on the traditional division of roles between men and women, and intergenerational relations - based on obligations. This is reflected in the processes of formation and functioning of the family, which is traditional, but also the dominant form of the family is marriage.

- Supporting active paternity,

- One of the characteristic features in the Mediterranean family model is

- its diversity of territorial division: the north - south. In both „submodels", previously mentioned characteristics, appear but with varying degrees of intensity. 
- Family models are differ: the frequency of marriages, the prevalence

- cohabitation, the number of children, the frequency of divorce, professional activity women. However, changes take place much faster in the north.

- The participation of women in the labor market has increased from the beginning of the seventies. Nevertheless, the rate for women is lower than in other European countries.

\section{Demographic conditions}

Despite the widespread of sharing these values in southern European countries, we also observe changes in families (Eurostat Yearbook 2012 \& Testa 2012):

- The population over the last five years has remained at a similar level (the lowest population found in Portugal (10.5 million), the highest in Italy (almost 61 million).

- The number of live births from 2008 shows a „drastic” downward trend, even a few million a year.

- As part of the fertility situation it is unfavorable and far from the level of assurance regarding replacement of generations:

- A drastic fall in fertility. The fertility rate amounting to an average of 1.32 does not provide replacement of generations and is one of the lowest in the EU.

- The average age for women giving birth to children has increased to 30 years.

- Extended life expectancy. For women it is 83.4 years and 75.3 for men.

- In terms of marriage and factors relating to the family situation is as follows:

- The propensity to marry is declining.

- In EU countries, it is quite a common trend for quick ,independence” of young people from their parents, and with the independent living, this trend is the least visible in the south Europe. Young people from Mediterranean countries live with their parents. The opportunity to stay in the family home provides them with economic support without restricting personal freedom.

- In comparison with other countries, birth outside marriage are much less common in the south European countries, however, here they are also increasingly popular. Patterns of family breakdown are conditioned by the late introduction of the law to divorce as well as 
the principles of rule dissolution of marriage by divorce.

- An increasing number of single-parent families, although their share in the total number of families is lower than in other Western European countries.

\section{Institutional support for families}

The immediate executor of the family policy are the local authorities. At the local level are offered: babysitting, health services, family counseling and legal, special services for families.

In pursuing these objectives, non-profit organizations and volunteers are participating.

A family associations representing their interests has not developed sufficiently, although there are various initiatives for the development of free time for children.(Balcerzak-Paradowska 2004, 182; Balcerzak-Paradowska, Kołaczek, Głogosz 2009, 126-130).

\section{Legal conditions}

In the Southern European model can be find a solution similar to that used in the conservative model, and the differences are especially connected to policy towards families and children. The model is characterized by a special feeling of family union, focusing on the protection of traditional family model and structure, to maintain family cohesion and strong family links. This reduces the liability of the State for the development of appropriate action. Social benefits are fragmented, unevenly distributed and generally at a low level. The family policy of southern European countries is dominated by the principle of subsidiarity and family solidarity. Family relatives are required to help and support (vertical and intergenerational solidarity). National laws in respect of the benefits for families divided for various forms of support are applicable.

\section{Family Policy instruments}

Family policy instrument of southern European countries which are having a universal character is the tax system with some relief including the family situation of the taxpayer. Family allowances are granted only to families who meet certain income criteria (means tested).

Benefits designed to facilitate the reconciliation of work and family responsibilities is the ability to take advantage of maternity and parental leave. Part-time employment of family reasons, financing costs of child care in kindergartens, additional parental leave for fathers. The characteristics of this 
system are (Dragan, Krasnowolski, Tracz-Dral, Fibingier 2011, 14; BalcerzakParadowska, Kołaczek, Głogosz 2009, 126-130):

- As part of the early childhood - parental leave for mothers and fathers - unpaid leave.

- Supporting families with many children through increased family allowances

- Helping single-parent families - they have additional rights and it includes eg. increased benefit for a small child.

- Supporting dysfunctional families, especially children and young people in these families (orphans, youth at risk).

Central European Model (continental, conservative) - Germany, France, Belgium, Holland, Austria, Luxemburg

\section{Axiological conditions}

Central European model of family Policy based on the values as follows (Balcerzak-Paradowska 2004, 184; Anioł 2010, 41-42; Durasiewicz 2013, 145):

- The family is considered as the basis for social cohesion and a place of education of successive generations.

- The family is seen as a personal development of its members. This is not equivalent to treating the family as an institution based on a formal marriage.

- The importance of having children. There are even some trends that identifying having children with patriotic attitudes, because of the threat of disequilibrium in the mechanism of population reproduction.

- The importance of ensuring adequate living conditions and livelihoods for families corresponding to the formula of ,prosperity without work".

\section{Demographic conditions}

In addition to the mentioned values, in the continental countries changes in the families are dynamic and characterized by the following features (Eurostat Yearbook 2012 \& Testa 2012):

- Population increases (the lowest populations inhabit in Luxembourg (0.5 million), the highest in Germany ( 81.8 million). The rising of life expectancy. For women is 83.8 years, for men 75.3. The highest rate of women across the EU was recorded in France and amounted to 83.8 years. 
- In terms of fertility, the situation is better than in the case of South European model:

- In the last five years the number of live births showed a downward trend, but in 2014 started to increase

- The average number of births is reduced (eg. France 2.01). This is due to the introduction of more family-friendly public policy, which includes: the initiation of accessible and affordable childcare, more flexible forms of employment.

When it comes to marriages and shaping the attitudes of the Central European family model the situation is as follows:

- The propensity to marry is declining and decision of marriage is shifting towards later times (the average age for women giving birth to children has risen to more than 30 years).

- Growing phenomenon of family breakdown through divorce.

Regarding to the activity of women and illegitimate births in the Central European model are as follows:

- The dynamic growth of economic activity of women

- France is a country with a relatively high rate of illegitimate births, lower than in the Nordic countries.

\section{Institutional family support}

In this model, the dominant subject of a French family policy is the State, acting directly or through social security institutions (which is part of the Cash Family Allowances). Decentralization of the right of the State is to increase the share of local governments in the tasks of family policy. Public support from the State and local communities (municipalities) is associated with self-help. Nongovernmental organizations representing the interests of families are involved in the discussion of family policy, and specific solutions are subject to public consultation (Balcerzak-Paradowska 2004, 185; Balcerzak-Paradowska, Kołaczek, Głogosz 2009, 97-100).

\section{Legal conditions}

The conservative system is very popular among continental part of Europe. It is a combination of family responsibility and strong regulation of the State. The social security system is based on the principle of insurance. The system maintains the traditional objective of the idea that the man is the main breadwinner and whose ability in this area should be supported. Family policies are based on the principle of subsidiarity, including - their foresight citizens 
expressed through participation in the system of insurance. Public support - from the state and local communities (municipalities) is associated with self-help. Applicable national laws in respect of the benefits for families divided for various forms of support

\section{Family Policy instruments}

In the continental countries (Germany, Austria, France, Belgium, Luxembourg and some parts of Netherlands) family policies based on the principle of subsidiarity, including - foresight of the citizens which is showed through participation in the system of insurance.

Money transfers are more likely to use than benefits in kind. The system of money transfers used in the family policy (eg. France) is developed, based on different principles (universality, but also depends on family income), taking into account the different situations and needs of families. These policies are intended to support the traditional family. The characteristics of this system are (Durasiewicz, 2012, pp. 89-121):

- In the context of child care (child-raising allowance and parental benefit, sick care),

- Widely developed activity of employers (reduction of working time, individual time schedules of work, part-time employment caused by family reasons - Germany)

- Supporting families by investing in the young generation (family allowance for all families, benefits in case of death of the breadwinner, the orphan's pension, widow's pension),

- Tax benefits (regardless of other family benefits, there are tax credits for children, as well as relief related to education, training and care, and children up to the age of 14 are entitled to a tax credit if they require to employ a guardian),

- Social services for children and youths (every child from the age of three years has a right to have a place in a public kindergarten),

- Health services (family health insurance system protects against social exclusion of children by providing them an access to prevention, care and medical treatment. Moreover, children and youths under the age of 18 are exempt from fees for preventive examinations and vaccinations. 


\section{Liberal model (Anglo-Saxon) - Great Britain, Ireland}

\section{Axiological conditions}

Liberal model of family policy is based on the following values (Kowalski 2010, 53):

- The family is considered as the basic unit in the education of successive generations, but having children is a private matter of parents.

- The family should take responsibility for themselves. As a result, there is a small range of support for families of universal character.

\section{Demographic conditions}

In addition to mentioned values among the family, in Anglo-Saxon countries demographic there are demographic changes which are characterized by the following features (Eurostat Yearbook 2012 \& Testa 2012):

- Population levels are growing and show an increase trends for the coming years,

- United Kingdom is one of 4 EU countries, deciding on $54 \%$ of the population of the EU (Germany, France, Great Britain, Italy).

- $\quad$ Extended life expectancy. For women is 80 years for males 79.0.

In terms of fertility, the situation is similar to the Central European model and approaching the countries from this model to get simple replacement of generations:

- An increasing number of life births,

- Fertility rate on the level of 2.01.

Within the factors related to family and marriage:

- An increasing number of a single-parent

- The propensity to marry is declining and decision of marriage is shifting towards later times, this is due to the desire for career development of young people

- A growing universality of partnership (eg. LAT - Living Apart Together).

Regarding to the Professional activity:

- The dynamic growth of women economic activity. 


\section{Institutional family support}

Liberal model is characterized by reference to the market and the family as the basic unit of prosperity guarantor. The unit is primarily responsible for overcoming social problems - can create all kinds of community.

The state is seen as an institution of last resort in providing assistance to individuals in the field of prosperity the individual - therefore, the size of the redistribution, resulting from social policy, are relatively small (Kowalski 2010, pp. 53-54).

\section{Legal conditions}

In the liberal model the responsibility of the state is kept to a limited extent. Citizens should be responsible for their situation and the market should fight against social risks through the offer activities to support individual activity of citizens and families. Whereas, the state supports active family activities (units) through an appropriate tax system and social benefits, their level is rather low. Family policy is based on the principle that the family should first takes all the responsibilities for themselves. As a result, there is little support of universal character. National laws are applicable on the ground of the benefits for families divided for various forms of support.

\section{Family Policy instruments}

Family and social policy of Anglo-Saxon countries (UK and Ireland) is based on the mentioned principle that the family should take all responsibilities for themselves. The assistance for low-income families dominates and family policy is currently focused on the fight against poverty,

Characteristic features of his system are: (Durasiewicz, 2012, pp. 108120):

- In the context of a child care (care for pregnant women, benefits and sick leave, free antenatal and child care up to 6 weeks of age, care without parents, care for a small child)

- Supporting families by investing in the young generation (family allowance for all families regardless of income, the allowance for single-parent families, the allowance for abandoned wives, widow's pension program for poverty reduction, provision of care for families with a disabled child)

- Tax benefits (mainly for single-parent families, tax relief for families with a disabled child, family allowances for parents with young 
children)

- Social services for children and youth (financing of nurseries and kindergartens, childcare centers, playgroups, babysitters for children called. Babysitteres, care centers and environmental, educational childcare allowance, clothing and footwear, school, subsidizing the purchase of textbooks, free rides to school, education allowance for children from rural areas, school feeding)

\section{Post-socialist model - Poland, Bulgaria, Slovenia}

\section{Axiological conditions}

Post-socialist model of family policy is based on the following values:

- The family, based on marriage is in this model a long and established tradition. This involves the influence of the Catholic religion, the lifting of the sacrament of marriage to the rank and indissoluble relationship.

- Marriage and the family occupied and occupy a high position in the hierarchy of generations entering adult life.

- There are changes in the pattern of marriage, consisting of moving a decision in time, which makes the family assume people socially mature, with greater financial independence. This phenomenon carries serious negative consequences for the process of procreation, it is in fact the most common implementation of the model family with fewer children.

\section{Demographic conditions}

Compared to previous models of family policy, post-socialist model falls the least when it comes to the demographic situation and is characterized by the following features (Durasiewicz, 2012, 9-17):

- Declining population.

- $\quad$ Extended life expectancy. For women it is 72.7 years, 81.1 for men.

In terms of fertility, the situation is unfavorable in comparison with other models of family policy:

- Low fertility rates (Poland fertility of only 1.29 children per woman slipped in the global statistics on the thirteenth position from the end )

- Decreasing the number of live births. 

follows:

In terms of factors related to marriage and the family situation is as

- The propensity to marry is declining and decision of marriage is shifting towards later times (In most cases this is due to the desire to achieve stability in the labor market, financial and housing of young people).

When it comes to marriages and shaping the attitudes of family in the postsocialist model, the situation is as follows:

- Decreasing the number of marriages.

- In comparison with other countries of birth outside marriage in the countries of post-communist model are much rarer, but also their

- growth.

- Dominant model of the family is marriage with one child.

- An increasing number of single-parent families, although their share in the total number of families is low.

\section{Institutional family support}

The dominant subject of family policy is the State, acting in a direct and separating the various tasks and funding for provincial and local government units.

\section{Legal conditions}

The accession in 2004 of new EU countries of the former communist bloc has raised the need to broaden the analysis of their family policies. Ch.Saraceno notes that - generally speaking - model of these policies can be considered close to the Social Democratic (characteristic of the Nordic countries) (Saraceno 2007), based on respect for the right to help enjoyed by citizens (the part of the benefit is targeted only for employees) and taking into account the principle of gender equality. Applicable national laws in respect of the benefits for families divided for various forms of support.

\section{Family Policy instruments}

The aim of family policy model post-communist countries (Poland, Bulgaria, Slovakia) is to increase the protection of families in difficult circumstances. The dominant instrument, which was used in this model are cash benefits. This model is based primarily on: the protection of the poorest families, the selectivity of the granting of benefits (Kangas \& Rostgaard 2007), equality 
rights for women and men to benefits and aims to enhance the impact on the course of demographic processes through the instruments of family policy explicitly and implicitly. The characteristics family support in this system are (Durasiewicz, 2012, pp. 27-43):

- Supporting families by investing in the young generation (family allowance additives, temporary allowance, allowance having a selective nature (depending on income), lump-sum aid for childbirth, additional benefits for people who have not yet had the rights to maternity leave that is, students, people working on contract for work, the insured in KRUS or seeking work (unemployed).

- Tax credits (System of pro-family tax deductions preference for large families).

- Social services for children and youth (difficult access to care and educational institutions - insufficient number of nurseries and kindergartens and places in nurseries and kindergartens.

- Support for single-parent families (the maintenance fund for singleparent families - but just as in the case of the US mother single parents with a child without an established paternity is not entitled to any benefits).

\section{Conclusions and recommendations for Polish}

The European Model Scandinavian (social democratic)

Characteristic family policy of Scandinavian countries is understood as friendly policy towards family, women and children. Extremely important solutions used in the Nordic countries are: the parental leaves (parental). In Sweden, institutional care is preferred to parental and therefore there is developed a network of appropriate services and - most important - is offered support to use them. It is one of the most advantageous solution, which allow for free choice of the method of care. It is followed by a more flexible choice of parental leave. You can use it all at once or divide accordingly to the needs of the family (with the consent of the employer). Increasingly, there is a possibility of free distribution of leave between both parents and the child's ability to share leave parts.

Therefore, in Poland, the area where you need significant changes is still parental leave. It is all about the problem of compensation of salary for the duration of leave. A partial solution to this situation may be the implementation of the current draft of the Act of 2016 by the state aid in the education of children. 


\section{The Central European Model (continental, conservative)}

In order to strengthen the role of direct financial assistance to Polish families who cover costs of education and care of the young children, it is needed to raise the income threshold for eligibility for family benefits. The transition from the current selective system of family benefits to the universal system (functioning not only in Germany but in most EU countries) would be an expression of support for all families with children. It would limit such cases where the risk of losing family benefits (after exceeding the income threshold constituting a criterion for entitlement) act as a brake on additional professional activity or moves person to black market o employment. It is worth to consider the inclusion of benefit possibility to cover estimated expenses associated with the covering of children upbringing costs (educational, cultural, recreational, etc.). Another form of family benefits could be setting them with comparison to other benefits (eg. In Germany Kinderzuschlag) - which could be compared to average costs incurred by families. Based on the pattern of Germany and France, there should be used higher level of benefits and selection of securing of social risks.

\section{European liberal model (Anglo-Saxon)}

According to OECD data from 2013, the United Kingdom is the second European country after France with regard to money spend from budget on children. It spends $3.6 \%$ of GDP on this aim. British family policy solutions create an extremely wide range of activities and forms of assistance, where in any case take into account the need to ensure that families with children material means of subsistence. Noteworthy is also the variety of life situations taken into account by the legislature - new forms benefit Working Tax Credit and Child Tax Credit (also appearing in the American model). Noticeable is also a particular concern for vulnerable groups, and the basic principle of action in this area is to equalize opportunities for children from different backgrounds. It should also be emphasized - as it seems - specific approach to the problem of combining professional duties with the care of dependent family members and the special role of employers in this area. The Polish state should model it solutions on British example with this regard. Government program aims to give every child the best start in life. It recognizes the that required for this purpose is a combination of early education, childcare, health and family benefits. Deemed necessary to increase the availability of child care for all children, improve health and emotional development of children, as well as supporting functions parental and aspirations of parents related to employment. 


\section{The European Model South European (Mediterranean)}

In all the countries analyze, we can observe the development of solutions to create opportunities to care for small children. This is done also in the countries of the South European model, which are dominated by the familiarism principle. This is because of the dynamics of professional activation of women, but to an even greater extent, the treatment of institutional care as part of the education system. The actions are moving in two directions: to support the care provided within the family, mainly through solutions to reconcile professional duties mother and father and family responsibilities and to support the development of care facilities.

In countries with active family policies, the development of both courses of action occurs in parallel and can be taken as a model to adapt the Polish system. In conclusion, it should be emphasized that the implementation of the family policy of encouraging families to invest in the young generation and provide him good conditions for development, followed by the use of the best ways to care for small children.

\section{References}

Anioł, W. (2010). Dywergencja i konwergencja w rozwoju polityki społecznej, Uniwersytet Warszawski, Studia Europejskie 4/2010.

Anioł, W. (2013). Dylematy polityki rodzinnej w Europie na przykładzie doświadczeń skandynawskich, Uniwersytet Warszawski, Studia Europejskie 1/2013.

Balcerzak-Paradowska, B. (2004). Rodzina i polityka rodzinna na przelomie wieków, IPiSS, Warszawa.

Balcerzak-Paradowska, B., Kołaczek, B., Głogosz, D., (2009). Polityki rodzinne w poszczególnych krajach UE [w:] Polityka rodzinna w karach UE - wnioski dla Polski M. Kubik (red.), Biuro Rzecznika Praw Obywatelskich, Warszawa.

Chełstowska, A. \& Zarzyńska, A. (2014). Urlopy dla ojców w kontekście różnych modeli polityki rodzinnej w Europie, Instytut Praw Publicznych, Warszawa.

Durasiewicz, A. (2012). Efektywność polskiej polityki rodzinnej na tle wybranych krajów UE, Wydawnictwo Politechniki Radomskiej, Radom.

Durasiewicz, A. (2013). Ogólnonarodowe rozwiqzania $w$ zakresie polityki rodzinnej na przykładzie wybranych krajów - rekomendacje dla Polski - w: „Umiędzynarodowienie polskiej polityki społecznej - aspekty globalne i europejskie" pod redakcją Katarzyny Głąbickiej i Michała Kubiaka, wyd. Uniwersytet Gdański \& PTPS, Gdańsk.

Fibingier, E., Dragan, A., Krasnopolski, A., Tracz-Dral, J., (2011). Zasitki rodzinne w wybranych państwach europejskich, Biuro Analiz i Dokumentacji Kancelarii Senatu, Warszawa.

Kangas, O. \& Rostgaard, T. (2007). Preferences or institutions? Work-family life opportunities in seven European countries [w:] Journal of European Social Policy 2007/17/03.

Kowalski, R. (2010). Polityka spoleczna jako instrument ksztaltowania zachowań jednostek, Polskie Towarzystwo Ekonomiczne, Kraków. 
SOCIETY. INTEGRATION. EDUCATION

Proceedings of the International Scientific Conference. Volume III, May $27^{\text {th }}-28^{\text {th }}$, 2016. 282-300

Saraceno, Ch. (2007). Family Policies in Europe; A comparative perspective, Polityka Społeczna, Special Issue of Polish Monthly Journal on Social Policy 2007.

Testa, M.R. (2012). Family Size In Europe: Evidence from the 2011 Eurobarometer Survey, Vienna Inst. of Demography, Austria 2012. 